\title{
CROWN ETHER(PHASE TRANSFER CATALYST) CONCENTRATION EFFECT ON KINETICS AND PRODUCT YIELD IN THE REACTION BETWEEN SOLID POTASSIUM $p$-NITROBENZOATE AND BENZYL BROMIDE
}

\author{
Sunil Kumar ${ }^{1, *}$ and Bigan Ram² \\ ${ }^{1}$ Department of chemistry, L.N Mithila University, Kameshwarnagar, \\ Darbhanga-846004, Bihar (India) \\ ${ }^{2}$ Department of Chemistry, Women's College, Samastipur-848101, Bihar (India) \\ *E-mail:delhi2014india@gmail.com
}

\begin{abstract}
18-Crown- 6 and other substituted 18-crown- 6 ether used to change kinetics and product yield .In solid liquid phase transfer reaction in between solid potassium p-nitrobenzoate and benzyl bromide in chloroform, Percentage product yield variation observed due to different electron donating group in Crown ether.In most of the cases concentration of crown ether catalyst is directly proportional to reaction rate and \% product yield .The reaction completed by nucleophilic substitution reaction mechanism.

Keywords: Crown ether, Lipophilicity, Electron donating group, Heterogeneousprocess, Nucleophilic substitution, Complex formation constants and Interionic ion- pair distance.
\end{abstract}

(C) RASĀYAN. All rights reserved

\section{INTRODUCTION}

Crown ethers have been at the center of immense scientific and technological interest. This has been motive by the fascinating features of these macromolecules which mimic at the simplest level the action of the true enzymatic systems. Specifically, crown ethers can serve as active carries and the last can catalyzes reactions on bound substrates. The efficiency of Crown ethers as phase transfer catalyst depends on their complex cation constant with the reaction ion pairs, their ability to enlarge the interionic pair distance and the lipophilicity of the ion pair complexes.In general, the PTC reaction describes a methodology for accelerating the reaction between ionic compounds and organic, water-insoluble substance in solvents of low polarity. In this solid liquid phase transfer reaction between potassium pnitrobenzoate and benzyl bromide 18 Crown 6,MB18C6,DH18C6 and B15C5 are used as phase transfer catalyst. The main aim of this experiment to observed variation of reaction rate and product yield when substituent of Crown ether changed.

\section{EXPERIMENTAL}

In a typical experiment chloroform (8ml) containing crown ether, $0.08 \mathrm{mmol}$ and $\mathrm{KNB} 1.2 \mathrm{mmol}$ was placed in a flask kept at $25 \pm 0.5^{\circ} \mathrm{C}$. After was stirring for $15 \mathrm{~min}, 2.5 \mathrm{M}$ Benzyl bromide was added . At intervals, depending on the reaction rate, a sample $(50 \mu \mathrm{l})$ of the clear chloroform solution was withdrawn and immediately diluted with chloroform solution $(10 \mathrm{ml})$ to quench the reaction.The Benzyl pnitrobenzoate product was determined quantitatively by HPLC. The reaction was usually monitored up to about $15 \%$ conversion.

\section{RESULTS AND DISCUSSION}

In this solid liquid phase transfer system, potassium p- nitrobenzoate is transferred to chloroform by means of the crown ether and the soluble crown ether potassium p-nitro benzoate complex(CR-KNB) is converted into p- nitro benzoate (BzNB) by treatment with benzyl bromide. .The mechanism of this heterogeneous process is depicted in Scheme-1 and equations 1 to 3. 
<smiles></smiles>

\section{\begin{tabular}{r|l}
$\mathrm{CHCl}_{3}$ & Crown ether \\
$25^{\circ} \mathrm{C}$ & $\downarrow$
\end{tabular}}

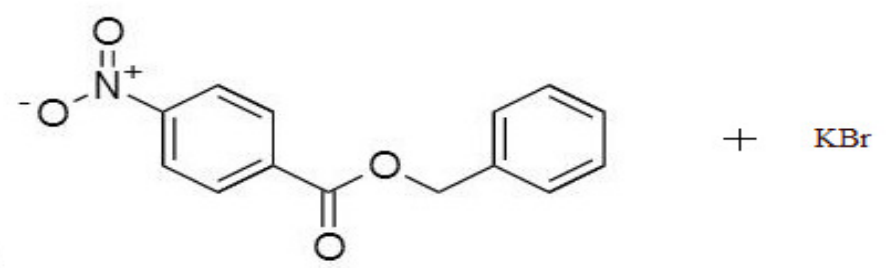

Scheme-1:The Reaction between solid Potassium $p$-nitrobenzoate and Benzyl bromide in chloroform

$\mathrm{CR}_{\mathrm{ORg}}+\mathrm{KNB}$ solid $\Leftrightarrow \mathrm{CR}-\mathrm{KNB}_{\text {org }}$

$\mathrm{CR}-\mathrm{KNB}$ org $+\mathrm{PhCH} 2 \mathrm{Br}_{\text {org }} \rightarrow \mathrm{PhCH} 2 \mathrm{NB}$ org $+\mathrm{CR}-\mathrm{KBr}_{\text {org }}$

$\mathrm{CR}-\mathrm{KBr}_{\text {org }} \Leftrightarrow \mathrm{CR}_{\text {org }}+\mathrm{KBR}$ solid

The following assumptions are made:

1. The phase transfer process (1) and (3) are much faster than the nucleophilic substitution reaction (2).

2. The concentration of the CR-KNB complex depends only on the initial crown ether concentration in the organic phase.

3. Crown ether complexation to $\mathrm{KNB}$ is appreciably greater than to $\mathrm{KBr}$ is appreciable, implying that the concentration of the CR-KNB remains essentially constant during the reaction. The rate of product formation is given by Equation-4, where $\mathrm{K}_{\mathbf{o b s}}$ is the pseudo- first order rate constant.Integration yields equation-5.Depending on reaction conditions, benzyl bromide can undergo either $\mathrm{SN}_{1}$ and $\mathrm{SN}_{2}$ reactions; hence the rate of product formation can be expressed as Equation-6, combining (4) and (6) yields equation-7 and thus $K_{1}$ and $K_{2}$ can be obtained by measuring $\mathrm{K}_{\mathrm{obs}}$ as a function of the Crown ether-salt complex concentration.

$\mathrm{d}\left[\mathrm{PhCH}{ }_{2} \mathrm{NB}\right] / \mathrm{dt}=\mathrm{K}\left[\mathrm{PhCH}{ }_{2} \mathrm{Br}\right][\mathrm{CR}-\mathrm{KNB}]=\mathrm{Kobs}[\mathrm{PhCH} 2 \mathrm{Br}]$

$-\mathrm{In}\left[\mathrm{PhCH} \mathrm{P}_{2} \mathrm{Br}\right]_{\mathrm{o}}-\left[\mathrm{PhCH}_{2} \mathrm{NB}\right]=\mathrm{Kobs}+-\mathrm{In}\left[\mathrm{PhCH}_{2} \mathrm{Br}\right]_{\mathrm{o}}$

$\mathrm{d}\left[\mathrm{PhCH}_{2} \mathrm{NB}\right] \mathrm{dt}=\mathrm{K}_{1}\left[\mathrm{PhCH}_{2} \mathrm{Br}\right]+\mathrm{K}_{2}\left[\mathrm{PhCH}_{2} \mathrm{Br}\right][\mathrm{CR}-\mathrm{KNB}]$

$$
=\left\{\mathrm{K}_{1}+\mathrm{K}_{2}[\mathrm{CR}-\mathrm{KNB}]\right\}\left[\mathrm{PhCH}{ }_{2} \mathrm{Br}\right]
$$

Kobs $=\mathrm{K}_{1}+\mathrm{K}_{2}[\mathrm{CR}-\mathrm{KNB}]$

Phase transfer equilibrium and extent of salt transfer using conditions similar to those employed in the kinetic studies.It was found that phase transfer equilibrium can be attained within 2 min. Figure-1 shows plots of UV absorbance versus time for transfer of KNB to chloroform containing Oxydimethylenebisbenzo-15-crown-5 and dicyclohexano-18-crown-6. The time needed to reach equilibrium is not affected by the rate of stirring or a change in particle size from 100 to 150 mesh but the 
use of non-ground KNB increases the equilibration time to $5 \mathrm{~min}$. These results justify the previously made assumption that the phase transfer step is much faster than ester formation, the half-life of which lie between $10^{2}$ and $10^{3} \mathrm{~min}$,depending on the crown ether used

The function $[\mathrm{CR}-\mathrm{KNB}] /[\mathrm{CR}]_{\mathrm{o}}$ can be used as a measure of the efficiency of a crown ether in transferring the solid KNB salt transferred into the organic phase.No detectable amount of salt is transferred in the absence of crown ether, but Table-1 shows that the above function reaches 0.95 for 18C6,MB18C6 and DH18C6 and 1.0 for bis B15C5, implying that nearly every crown ether molecule in the $\mathrm{CHCl}_{3}$ solution is bound to a $\mathrm{K}^{+}$ion. At $25^{\circ} \mathrm{C}$ a complex concentration of $0.06 \mathrm{M}^{\text {in }} \mathrm{CHCl}_{3}$ can be easily attained.

Since $\mathrm{KBr}$ is a reaction product it conceivably could compete with KNB for crown ether and consequently lower the CR-KNB concentration during the reaction. However, during the reaction, the concentration of CR-KNB was found to be constant up to at least $20 \%$ conversion of $\mathrm{PhCH}_{2} \mathrm{Br}$.Also, addition of solid $\mathrm{KBr}$ in an amount equal to that produced after $20 \%$ conversion has no effect on the concentration of CR-KNB.Apparently, the reaction product $\mathrm{CR}-\mathrm{KBr}$ decomposes into solid $\mathrm{KBr}$ and free crown ether, the latter solubilizing solid KNB to maintain a constant CR-KBN concentration. The different behavior of $\mathrm{KBr}$ and $\mathrm{KNB}$ depends on such factors as the crystal lattice energy of the salt and the complex formation constants of the crown ether with the two salts.

Plots of $\mathrm{In}\left[\mathrm{PhCH}_{2} \mathrm{Br}\right]_{0}-\left[\mathrm{PhCH}_{2} \mathrm{NB}\right]$ versus reaction time for bis B15C5-catalyzed reaction of solid KNB with $\mathrm{PhCH}_{2} \mathrm{Br}$ at various crown ether concentrations are shown in Fig.-2. The observed pseudo first order rate constants, $\mathrm{K}_{\mathrm{obs}}$ calculated from the least squares straight lines are listed in Table-3 together with other reaction variables. It was ascertained that no reaction occurs in the absence of Crown ether.

Figure-3 depicts plots of Kobs versus the complexed salt concentration (Cr-KNB).All crown ethers show linear relations with intercepts very close to zero. The intercepts, representing $\mathrm{K} 1$ for benzyl bromide in $\mathrm{CHCl}_{3}$ at $25^{\circ} \mathrm{C}$ (equation-7), are less than $10^{-6} \mathrm{~min}^{-1}$. Small $\mathrm{SN}_{1}$ rate constants are expected since in a low polarity solvent such as chloroform the $\mathrm{SN}_{1}$ pathway is insignificant. The same reaction gave $\mathrm{K} 1=10^{-5}$ $\mathrm{min}^{-1}$ in the more polar solvent dichloromethane.

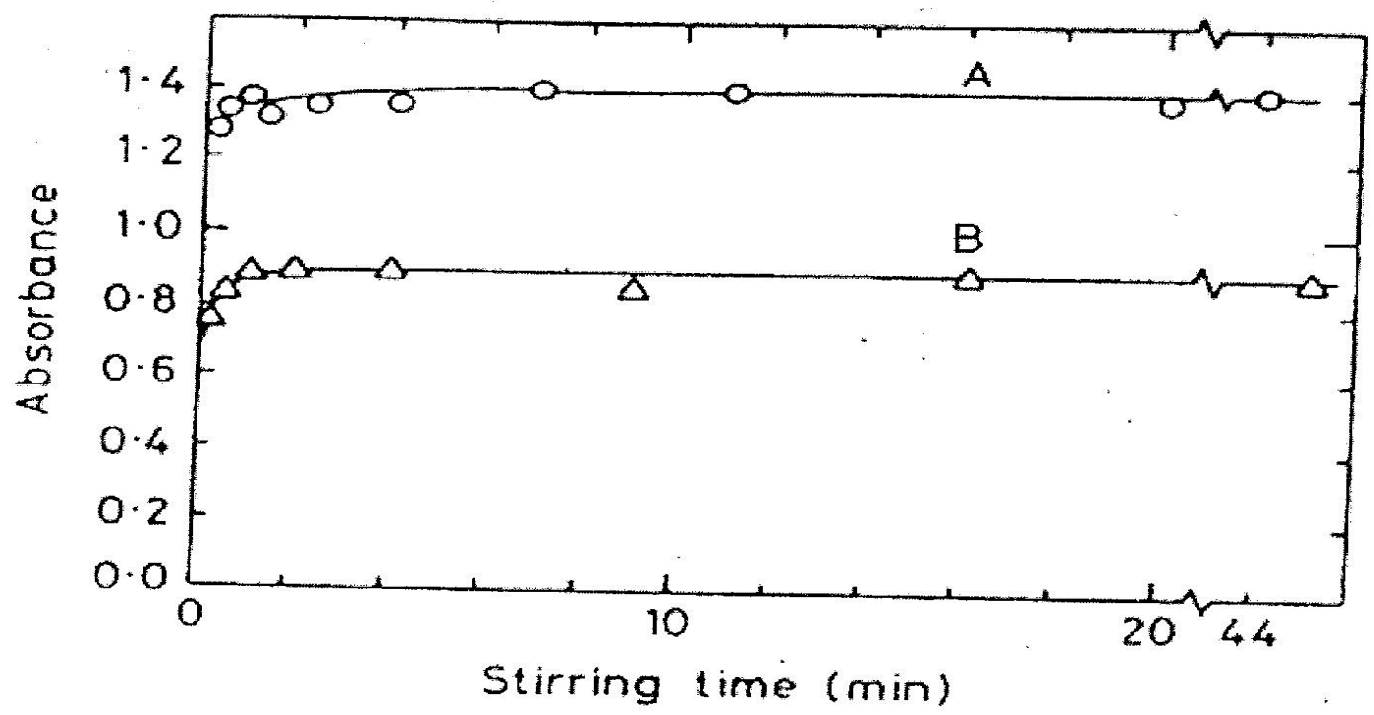

Fig.-1: Plots of the absorbance of the crown ether-potassium p-nitrobenzoate complex versus stirring time in solid $\mathrm{CHCl}_{3}$ phase-transfer process at $25^{\circ} \mathrm{C}: \mathrm{A},[\mathrm{bisB} 15 \mathrm{C} 5]=5.0 \times 10-3 \mathrm{M}$ at $K_{\max } .280 ;[\mathrm{DH} 18 \mathrm{C} 6]=5.0 \times 10^{-3} \mathrm{M}$ at $K_{\max } 272$ $\mathrm{nm}$; cell length $=1.0 \mathrm{~cm}$ (the sample was diluted 200 times before UV measurement)

The $\mathrm{SN}_{2}$ rate constants calculated from the slopes the plot of Fig.-3is listed in Table -2.The K2 values in the presence of 18Crown6, MB18 C6,DH18C6 differ by not more than a factor of 1.5, but the K2 values in the presence of bis B15C5 are about ten times larger.

The much higher $\mathrm{K} 2$ value with bis $\mathrm{B} 15 \mathrm{C} 5$ is most likely caused by the larger $\mathrm{CO}_{2}^{---} \mathrm{K}^{+}$interionic distance in its complex with the bis-crown ether.At the concentrations employed in these studies, the 
crown ether-salt complex in $\mathrm{CHCl}_{3}$ is undoubtedly an ion pair.Moreover,the concentration of the crown ether-ion pair complex indicates that the reaction proceeds via the ion pairs and that no reactive free ions are involved.Studies have shown that the interionic ion- pair distance in a crown ether ion pair complex is sensitive to the structure of the crown ether and the types of cation and anion composing the ion pair. In systems where 1:1 crown ether-cation complexes tight ions pairs are frequently observed in less polar media like $\mathrm{CHCl}_{3}$ or diethyl ether,especially for less delocalized anions. The interionic ion pair distance in the complexes appears to increase in the order 18C6 MB18C6<DH18C6<<bisB15C5. This change corresponds with the increase in K2 found for these crown ether (Fig.-2 and 3).

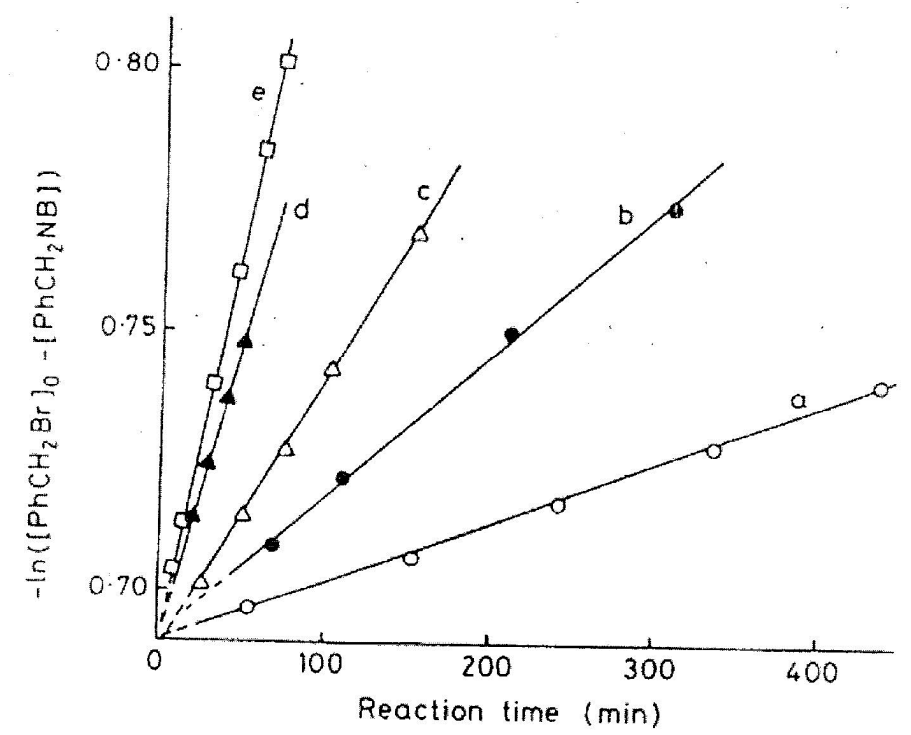

Fig.-2:Plots of $\ln \left[\mathrm{PhCH}_{2} \mathrm{Br}\right]_{\mathrm{o}}-\left[\mathrm{PhCH}_{2} \mathrm{NB}\right]$ versus reaction time for the solid $-\mathrm{CHCl}_{3}$ phase transfer reaction between potassium p-nitrobenzoate and benzyl bromide catalysed by oxymethylenebisbenzo- 15 -crown -5 at $25^{\circ} \mathrm{C}$ :

$\mathrm{a},[\mathrm{CR}]_{\mathrm{o}}=1.3 \times 10^{-3} \mathrm{M} ; \mathrm{b},[\mathrm{CR}]_{\mathrm{o}}=3.0 \times 10^{-3} \mathrm{M} ; \mathrm{c},[\mathrm{CR}]_{\mathrm{o}}=5.0 \times 10^{-3} \mathrm{M} ; \mathrm{d},[\mathrm{CR}]_{\mathrm{o}}=1.2 \times 10^{-2} \mathrm{M} ; \mathrm{e},[\mathrm{CR}]_{\mathrm{o}}=1.5 \times 10^{-2} \mathrm{M}$.

Table-1: Efficiency of transfer of solid potassium p-nitrobenzoate into chloroform by crown ethers at $25^{\circ} \mathrm{C}$

\begin{tabular}{l|l|c|c}
\hline S. No. & \multicolumn{1}{|c|}{ Name of crown ether } & $\begin{array}{c}\text { Fraction of crown ether complexed } \\
\text { to crown ether }\end{array}$ & $\begin{array}{c}\text { Concentration range of crown } \\
\text { ether10 } 2 \text { [Cr] } / \mathrm{M}\end{array}$ \\
\hline 01 & 18-Crown-6 & 0.95 & $0.50-5.0$ \\
\hline 02 & 4-Methylbenzo18-Crown-6 & 0.95 & $0.60-5.0$ \\
\hline 03 & Dicyclohexano 18-Crown-6 & 0.95 & $0.5-6.0$ \\
\hline 04 & $\begin{array}{l}\text { Oxymethylenebisbenzo 15- } \\
\text { Crown-5 }\end{array}$ & 1.0 & $0.13-2.3$ \\
\hline
\end{tabular}

Table-2: Second order rate constants $\left(\mathrm{K}_{2}\right)$ for the reaction between potassium p-nitrobenzoate and benzyl bromide catalyzed by crown ethers in $\mathrm{CHCl}_{3}$ at $25^{\circ} \mathrm{C}$

\begin{tabular}{c|c|c|c}
\hline S.No. & $\begin{array}{c}\text { Name of crown } \\
\text { ether }\end{array}$ & $10^{2} \mathrm{k}_{2} / 1 \mathrm{~mol}^{-1} \mathrm{~min}^{-1}$ & Range of crown ether concentration(10 $[\mathrm{CR}] / \mathrm{M})$ \\
\hline 01 & 18C6 & 1.30 & $0.50-5.00$ \\
\hline 02 & MB18C6 & 1.13 & $0.60-5.00$ \\
\hline 03 & DH18C6 & 1.84 & $0.50-6.00$ \\
\hline 04 & BisB15C5 & 9.66 & $0.13-2.25$ \\
\hline 05 & Mb15C5 & 0.14 & $1.00-7.00$ \\
\hline
\end{tabular}


RASĀYAN $J$. Chem.

Vol. 10 | No. 3 |929 - 934 | July - September | 2017

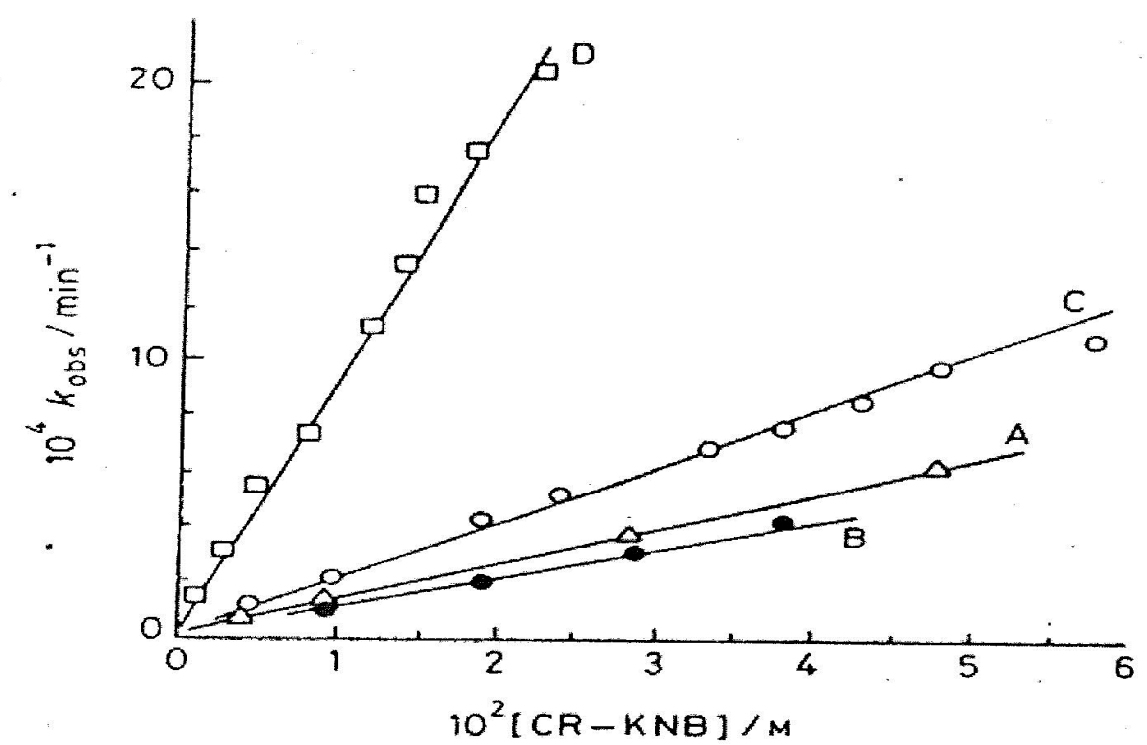

Fig.-3:Plots of Kobs versus[ $\mathrm{CR}-\mathrm{KNB}$ ] in the solid $\mathrm{CHCl}_{3}$ phase transfer reactions catalysed by various crown ethers at $25^{\circ} \mathrm{C}: \mathrm{A}, 18 \mathrm{C} 6, \mathrm{~B} \mathrm{MB} 18 \mathrm{C} 6, \mathrm{C}, \mathrm{DH} 18 \mathrm{C} 6, \mathrm{D}, \mathrm{BISB} 15 \mathrm{C} 5$.

Table-3: Pseudo-first-order rate constants, $\mathrm{K}_{\mathrm{obs}}$ for the reaction between potassium $\mathrm{p}$-nitrobenzoate and benzyl bromide in a solid- $\mathrm{CHCl}_{3}$ phase transfer system catalyzed by various crown ethers at $25^{\circ} \mathrm{C}$

\begin{tabular}{|c|c|c|c|c|c|c|}
\hline Crown ether & $\frac{10^{2}\lceil\mathrm{CR}]_{0}}{\mathrm{M}}$ & $\underset{\mathrm{M}}{\left[\mathrm{PhCh}_{2}\right.} \underline{\mathrm{Br}_{0}}$ & $\frac{\mathrm{Wt}, \mathrm{KNB}}{\mathrm{g}}$ & $\frac{10^{2}[\mathrm{CR}-\mathrm{KNB}]_{\mathrm{o}}}{\mathrm{M}}$ & $\frac{10^{4} \mathrm{~K}_{\text {obs }}}{\mathrm{MIN}^{-1}}$ & $\frac{\text { Conversion }}{(\%)}$ \\
\hline \multirow{4}{*}{$18 \mathrm{C} 6$} & 0.48 & 0.481 & 0.15 & 0.46 & 0.69 & 0.9 \\
\hline & 1.00 & 0.506 & 0.15 & 0.95 & 1.24 & 4.5 \\
\hline & 3.00 & 0.253 & 0.10 & 2.85 & 3.63 & 5.7 \\
\hline & 5.00 & 0.252 & 0.20 & 4.75 & 6.17 & 6.0 \\
\hline \multirow{4}{*}{ MB18C6 } & 1.00 & 0.503 & 0.20 & 0.95 & 0.98 & 3.6 \\
\hline & 2.00 & 0.503 & 0.20 & 1.92 & 1.92 & 6.3 \\
\hline & 3.00 & 0.503 & 0.25 & 2.88 & 3.09 & 9.7 \\
\hline & 4.00 & 0.503 & 0.25 & 3.80 & 4.72 & 11.0 \\
\hline \multirow{9}{*}{ DH18C6 } & 0.50 & 0.500 & 0.25 & 0.48 & 1.08 & 3.8 \\
\hline & 1.00 & 0.500 & 0.25 & 0.95 & 2.19 & 10.8 \\
\hline & 2.00 & 0.500 & 0.25 & 1.90 & 4.25 & 16.4 \\
\hline & 2.52 & 0.490 & 1.00 & 2.39 & 5.23 & 15.0 \\
\hline & 3.50 & 0.500 & 0.25 & 3.80 & 6.87 & 10.6 \\
\hline & 4.00 & 9.500 & 0.25 & 3.80 & 7.45 & 7.6 \\
\hline & 4.50 & 0.500 & 0.25 & 4.28 & 8.49 & 10.9 \\
\hline & 5.00 & 0.500 & 0.25 & 4.75 & 9.83 & 16.8 \\
\hline & 6.00 & 0.500 & 0.25 & 5.70 & 10.8 & 17.0 \\
\hline \multirow{9}{*}{ Bis B15C5 } & 0.13 & 0.501 & 0.25 & 0.13 & 1.16 & 4.8 \\
\hline & 0.30 & 0.501 & 0.25 & 0.30 & 2.85 & 10.1 \\
\hline & 0.50 & 0.501 & 0.25 & 0.50 & 5.38 & 7.5 \\
\hline & 0.80 & 0.501 & 0.25 & 0.80 & 7.28 & 5.0 \\
\hline & 1.20 & 0.501 & 0.25 & 1.20 & 11.1 & 5.5 \\
\hline & 1.35 & 0.501 & 0.25 & 1.35 & 13.5 & 9.5 \\
\hline & 1.50 & 0.501 & 0.25 & 1.50 & 15.8 & 10.4 \\
\hline & 1.80 & 0.501 & 0.25 & 1.80 & 17.5 & 8.3 \\
\hline & 2.20 & 0.248 & 0.25 & 2.25 & 20.4 & 9.6 \\
\hline
\end{tabular}




\section{CONCLUSION}

In conclusion, we have demonstrated a method for the synthesis of Benzyl p-nitrobenzoate from potassium p-nitrobenzoate and benzyl bromide in chloroform by using Crown ether phase transfer catalyst .The yields are quite good and the reactions are faster. The concentration of crown ether catalyst is directly proportional to rate constant and product yield. When different electron donating group used in Crown ether, the variation observed in rate constant and product yield. It is found that the presence of more electron donating group increases the reaction rate and product yield.

\section{ACKNOWLEDGEMENT}

One of the authors (Sunil Kumar) is thankful to Prof. I. S Jha and Prof. S. Jha, Department of Chemistry, L.N. Mithila University, Darbhanga for providing valuable suggestions and constant support to carry out present Research work.

\section{REFERENCES}

1. Sanjeev D. Naik and L.K. Doraiswamy, Chemical Engineering Science, 52(24),4533( 1997)

2. Ganapat D. Yadav and Man Mohan Sharma, Ind. Eng. Chem. Process Des. Dev., (20), 385(1981)

3. Kam-Han Wong and Alex P. W. Wai, Journal of the Chemical Society, Perkin Transactions, 2(3)213(1983)

4. Sergio. Alunni, Enrico. Baciocchi and Piero. Perucci, J. Org. Chem., 41 (15),2636( 1976)

5. Angela K. Dillow, S. L. Jimmy Yun, David Suleiman, David L. Boatright, Charles L. Liotta, and Charles A. Eckert, Ind. Eng. Chem. Res, 35 (6), 1801(1996)

6. Hayder A. Zahalka, Yoel Sassonand Oel Sasson., Can. J. Chem., 67, 245 (1989)

7. Arthur W. Herriott and Donald Picker. J. Am. Chem. Soc, 97 (9), 2345( 1975)

8. I. A. Esikova, and S. S. Yufit, Physical Organic Chemistry, 4(3), 149,157 ( 1991)

[RJC-1790/2017] 